\title{
Upaya Meningkatkan Kinerja Guru Melalui Supervisi Akademik Kepala Sekolah Di SMK Negeri 2 Wonosari
}

\author{
Supoyo \\ Kepala SMKN 2 Wonosari \\ supoyo@gmail.com \\ Received: 04 March 2021; Revised: 26 April 2021; Accepted: 28 July 2021 \\ DOI: http://dx.doi.org/10.37905/aksara.7.3.1193-1200.2021
}

\begin{abstract}
Abstrak
Kemampuan guru dalam menguasai bahan pelajaran pada umumnya sangat menghawatirkan karena dari sampel guru yang diminta menunjukkan kemampuan menguasai bahan pelajaran $70 \%$ yang kurang menguasai bahan pelajaran, sedangkan hanya 30\% yang menguasai bahan pelajaran. Kondisi seperti itu diperparah dengan kurang optimalnya fungsi kepengawasan Kepala Sekolah. Bila selama ini banyak pendapat menyatakan profesionalisme guru di Indonesia relatif rendah atau kurang memadai, hal itu merupakan akibat dari kurangnya kepengawasan kepala sekolah. Tujuan dari penelitian tindakan sekolah (PTS) ini adalah untuk mengetahui sejauh mana pembinaan kepala sekolah melalui supervisi akademik untuk meningkatkan kinerja guru dalam pengembangan evaluasi hasil belajar. Dalam penelitian tindakan sekolah (PTS) ini dilakukan dalam 3 siklus, dari hasil tindakan yang dilakukan terbukti dapat meningkatkan kinerja guru dengan mencapai standar ideal. Dari 41,18\% pada siklus I, dapat meningkat menjadi 70,59 \% pada siklus II, dan siklus ke III 76,47 \%. Hasil penelitian tindakan ini menunjukkan bahwa pembinaan melalui supervisi akademis kepala sekolah dapat meningkatkan kinerja guru dalam pengembangan evaluasi hasil belajar dengan ketuntasan mencapai $100 \%$.
\end{abstract}

\section{Kata kunci: Kinerja Guru, Evaluasi Hasil Belajar, Supervisi Akademik}

\section{PENDAHULUAN}

Perkembangan IPTEK yang berdampak pada kemajuan kehidupan manusia dewasa, ini telah membawa aplikasi tersendiri bagi dunia pendidikan. Oleh karena itu, pemangunan pendidikan di Indonesia dewasa ini diarahkan pada masalah peningkatan mutu dan relevansi, disamping masalah pemerataan dan efisiensi pendidikan Pemerintah telah menggariskan sebuah kebijakan untuk membenahi bidang pendidikan, satu diantaranya adalah kebijakan tentang pendidikan Sekolah Dasar.

Di Level pendidikan, upaya perbaikan makin diintensifkan dengan anggaran maupun sarana serta fasilitas belajar terus ditingkatkan. Namun kondisi pendidikan di tanah air hingga dewasa ini masih diliput oleh berbagai permasalahan. Secara kwantitatif masalah ini berkenaan dengan masalah kekurangan guru, masih banyak anak yang perlu bersekolah, tingginya angka putus sekolah (Droup Out) dan adanya perbedaan angka partisipasi kasar dan murni antara daerah perkotaan dan pedesaan. Sedangkan secara kualitas indikatornya antara lain adalah rendahnya daya serap anak didik, kurang 
relevannya program-program pendidikan dan semakin banyak lulusan sekolah menengah umum yang tidak dapat melanjutkan ke perguruan tinggi.

Ada berbagai faktor yang menyebabkan rendahnya mutu pendidikan, satu diantaranya adalah faktor guru, yang beupa : (1) kurang memahami konsep ajaran. (2) Lemah dalam aspek peadadogis, dan (3) tidak menguasai metode-metode yang relevan dalam proses belajar mengajar. Mengenai rendahnya kompetensi guru secara menyeluruh memang sukar dibuktikan, karena belum tersedianya studi yang secara komprehensif tentang hal tersebut. Tingginya kompetensi guru dapat dilihat dari kemampuan mengadakan perencanaan kegiatan belajar mengajar, baik berupa perencanaan materi, alat, maupun metode yang sesuai sehingga tujuan-tujuan yang telah dirumuskan dapat tercapai dengan sebaik-baiknya. Sebagaimana yang dikemukakan oleh Suryabrata (1984 : 247 - 248) sebagai berikut :

Karena kenyataan bahwa "belajar" dan "mengajar" adalah masalah setiap orang, maka jelaslah kiranya perlu dan pentingnya menjelaskan dan merumuskan masalah belajar itu, terlebih-lebih bagi kaum pendidikan profesional supaya kita menempuhnya dengan lebih efisien dan seefektif mungkin.

Berkembang tidaknya suatu pelaksanaan tugas guru, sebagian besar sangat ditentukan oleh kemampuan guru tersebut dalam merencanakan kegiatan belajar sebelum mengajar. Namun dalam kenyataan sehari-hari, masih ada di antara guru-guru yang belum mampu atau tidak memiliki keterampilan dalam merencanakan kegiatan belajar mengajar, bahkan ada diantara guru yang tidak ada persiapan dalam mengajar. Untuk mendapatkan informasi yang lebih jelas mengenai permasalahan yang diduga di atas, studi ini ingin meneliti tentang kompetensi guru dalam melaksanakan kegiatan belajar mengajar di SMK Negeri 2 Wonosari.

Kompetensi guru mencakup dimensi yang luas dan studi ini dibatasi pada salah satu dimensi yaitu kompetensi mengajar yang merupakan bagian dari kompetensi profesi guru. Sesuai dengan latar belakang masalah secara umum rumusan masalah yang dianjurkan adalah sampai dimana penguasaan kompetensi guru dilihat dari mengajar.

Dalam hal ini untuk mengungkapan kondisi permasalahan guru, khususnya kompetensi mengajar SMK Negeri 2 Wonosari, oleh karena itu penelitian ini memiliki relevansi praktis dengan kebijakan-kebijakan pendidikan yang digalakkan pemerintahan saat ini, seperti kebijakan peningkatan mutu guru, sehingga temuan penelitian ini dapat dipakai oleh pihak terkait untuk memperbaiki keadaan sesuai dengan kebijakan yang digariskan pemerintahan.

\section{METODE PENELITIAN}

Penelitian ini merupakan penelitian tindakan kelas yang menggunakan data pengamatan langsung terhadap jalannya proses pembelajaran di kelas. Dari data tersebut kemudian dianalisis melalui beberapa tahapan dalam siklus-siklus tindakan.

Penelitian tindakan sekolah ini dilaksanakan di SMK Negeri 2 Wonosari. Alasan utama dari hasil pengamatan langsung dan informasi yang di terima, bahwa sebagian guru di SMK Negeri 2 Wonosari belum memiliki kinerja yang baik dalam melaksanaan kegiatan belajar mengajar karena guru belum mampu menyusun agenda PBM yang baik yang sesuai dengan keadaan dan kondisi sekolah masing-masing. Hal ini desebabkan oleh kurangnya informasi yang diterima dan mengingat juga dengan tugas-tugas guru yang 
sangat banyak dan kompleks dan belum memiliki tenaga tata usaha yang seyogyanya dapat membantu tugas kepala sekolah.

Pelaksanaan penelitian menetapkan setting dua siklus, pada masing-masing siklus dilaksanakan melalui empat tahapan yaitu: (1) perencanaan penelitian, (2) pelaksanaan penelitian, (3) observasi/ evaluasi, dan (4) refleksi.

Observasi dilakukan oleh peneliti pada saat guru SMK Negeri 2 Wonosari menyusun satuan pelajaran yang baik di pertemuan tersebut, baik secara individu maupun kelompok.

Subyek dalam penelitian ini adalah Guru SMK Negeri 2 Wonosari tahun pelajaran 2020/2021. Jenis penelitian ini adalah penelitian tindakan sekolah melalui penerapan supervisi akademis Kepala Sekolah. Jumlah guru yang menjadi obyek dalam penelitian ini adalah sebanyak 17 orang.

Adapun skala yang digunakan adalah sekala Likert dengan lima katagori sikap yaitu : sangat tinggi, tinggi, sedang, rendah dan sangat rendah. Penilaian dilakukan dengan memberikan skor pada kolom yang tersedia dengan ketentuan sebagai berikut: skor $5=$ sangat tinggi, skor $4=$ tinggi, skor $3=$ sedang, skor $2=$ rendah, dan skor $1=$ sangat rendah.

\section{HASIL DAN PEMBAHASAN}

\section{Siklus I}

a) Tahap Perencanaan

Pada tahap ini peneliti mempersiapkan perangkat pembinaan yang terdiri dari rencana pembinaan, soal tes formatif 1 dan alat-alat pembinaan lain yang mendukung. Selain itu juga dipersiapkan lembar observasi peningkatan kinerja guru dengan pemberian balikan.

b) Tahap Kegiatan dan Pelaksanaan

Pengamatan (observasi) dilaksanakan bersamaan dengan pelaksanaan pembinaan di sekolah. Pada akhir proses pembinaan Kepala Sekolah diberi tes formatif I dengan tujuan untuk mengetahui tingkat keberhasilan Kepala Sekolah dalam meningkatkan kinerjanya sesuai dengan yang telah dilakukan. Adapun data hasil penelitian pada siklus I. Dari hasil observasi dapat dijelaskan bahwa dengan pembinaan yang dilakukan oleh Kepala Sekolah melalui supervisi akademis diperoleh nilai rata-rata peningkatan kinerja guru adalah 41,18\% atau ada 7 orang guru dari 17 orang sudah tuntas.

Hasil tersebut menunjukkan bahwa pada siklus pertama secara kelompok guru belum meningkat kinerjanya, karena yang memperoleh nilai $\geq 65$ hanya sebesar 43,82\% lebih kecil dari persentase ketuntasan yang dikehendaki yaitu sebesar $85 \%$. Hal ini disebabkan karena guru di SMK Negeri 2 Wonosari masih banyak yang belum memahami tentang supervisi akademis kepala sekolah tersebut

c) Refleksi

Dalam pelaksanaan kegiatan pembinaan diperoleh informasi dari hasil pengamatan sebagai berikut:

1) Kepala Sekolah masih kurang teliti dalam melakukan pembinaan di sekolah

2) Kepala Sekolah masih kurang baik dalam pemanfaat waktu

3) Kepala Sekolah masih kurang konsentrasi dalam melakukan pembinaan, karena ada trugas lain yang harus dikerjakan. 
d) Revisi Rancangan

Pelaksanaan kegiatan pembinaan pada siklus I ini masih terdapat kekurangan, sehingga perlu adanya revisi untuk dilakukan pada siklus berikutnya.

1) Kepala Sekolah perlu lebih terampil dalam memotivasi guru dan lebih jelas dalam menyampaikan tujuan pembinaan. Di mana kepala sekolah diajak untuk terlibat langsung dalam setiap kegiatan yang akan dilakukan.

2) Kepala Sekolah perlu mendistribusikan waktu secara baik dengan menambahkan informasi-informasi yang dirasa perlu dan memberi catatan

3) Kepala Sekolah harus lebih terampil dan bersemangat dalam memotivasi kepala sekolah sehingga kinerjanya lebih meningkat.

\section{Siklus II}

a) Tahap perencanaan

Pada tahap ini peneliti mempersiapkan perangkat pembinaan yang terdiri dari rencana pembinaan 2, soal tes formatif II dan alat-alat penilaian lain yang mendukung.

b) Tahap kegiatan dan pelaksanaan

Dalam hal ini peneliti bertindak sebagai Kepala Sekolah. Adapun proses pembinaan mengacu pada rencana pembinaan dengan memperhatikan revisi pada siklus I, sehingga kesalahan atau kekurangan pada siklus I tidak terulang lagi pada siklus II. Penelitian tindakan sekolah ini dilaksanakan sesuai dengan prosedur rencana pembinaan dan skenario pembinaan pada saat proses belajar mengajar berlangsung

Pada akhir proses pembinaan guru diberi tes formatif II dengan tujuan untuk mengetahui tingkat keberhasilan dalam meningkatkan kinerjanya. Instrumen yang digunakan adalah tes formatif II.

Dari hasil diperoleh nilai rata-rata peningkatan guru sekolah adalah 70,29\% dan peningkatan kinerja mencapai $70,59 \%$ atau ada 12 orang dari 17 orang guru yang sudah tuntas dalam meningkatkan kinerjanya. Hasil ini menunjukkan bahwa pada siklus II ini peningkatan guru telah mengalami peningkatan sedikit lebih baik dari siklus I. Adanya peningkatan kinerja guru ini karena setelah Kepala Sekolah telah menginformasikan bahwa setiap akhir pembinaan akan diadakan penilaian sehingga pada pertemuan berikutnya guru lebih termotivasi untuk meningkatkan kinerjanya. Selain itu guru juga sudah mulai mengerti apa yang dimaksudkan dan diinginkan oleh Kepala Sekolah dalam melakukan pembinaan supervisi akademis kepala sekolah.

c) Refleksi

Dalam pelaksanaan pembinaan diperoleh informasi dari hasil pengamatan sebagai berikut:

1) Memotivasi guru

2) Membimbing guru dalam menyusun rencana kerja guru merumuskan kesimpulan/menemukan konsep

3) Pengelolaan waktu

d. Revisi Pelaksanaaan

Pelaksanaan pembinaan pada siklus II ini masih terdapat kekurangankekurangan. Maka perlu adanya revisi untuk dilaksanakan pada siklus III antara lain: 1) Kepala Sekolah dalam memberikan pembinaan kepada guru hendaknya dapat 
membuat guru termotivasi dalam membuat program dan rencana sekolah.

2) Kepala Sekolah harus lebih dekat dengan guru sehingga tidak ada perasaan takut/malu dalam diri guru terutama dalam bertanya tentang masalah yang dihadapi oleh sekolah.

3) Kepala Sekolah harus lebih sabar dalam melakukan pembinan kepada guru terutama dalam merumuskan kesimpulan / menemukan konsep.

4) Kepala Sekolah harus mendistribusikan waktu secara baik sehingga kegiatan pembinaan dapat berjalan efektif sesuai dengan yang diharapkan.

5) Kepala Sekolah sebaiknya menambah lebih banyak contoh contoh program kerja dengan format format yang sudah distandardisasi oleh Departemen Pendidikan Nasional,dalam hal ini Lembaga Penjaminan Mutu Pendidikan (LPMP) baik di Tingkat Provinsi maupun tingkat Pusat.

\section{Siklus III}

a) Tahap Perencanaan

Pada tahap ini peneliti mempersiapkan perangkat pembinaan yang terdiri dari rencana pembinaan 3 , soal tes formatif 3 dan alat-alat pembinaan lainnya yang mendukung.

b) Tahap kegiatan dan pengamatan

Adapun proses pembinaaan mengacu pada rencana pembinaan dengan memperhatikan revisi pada siklus II, sehingga kesalahan atau kekurangan pada siklus II tidak terulang lagi pada siklus III.

Pengamatan (observasi) dilaksanakan bersamaan dengan pelaksanaan proses belajar mengajar berlangsung. Pada akhir proses pembinaan guru diberi tes formatif III dengan tujuan untuk mengetahui tingkat keberhasilan guru dalam meningkatkan kinerjanya yang telah dilakukan. Instrumen yang digunakan adalah tes formatif III

Berdasarkan hasil yang diperoleh nilai rata-rata tes formatif sebesar 76,47 \% dan dari 17 guru secara keseluruhan sudah mencapai ketuntasan dalam meningkatkan kinerjanya. Maka secara kelompok ketuntasan telah mencapai $100 \%$ (termasuk kategori tuntas). Hasil pada siklus III ini mengalami peningkatan lebih baik dari siklus II. Adanya peningkatan hasil pembinaan pada siklus III ini dipengaruhi oleh adanya peningkatan kemampuan Kepala Sekolah dalam menerapkan pembinaan melalui supervisi akademis sehingga guru menjadi lebih memahami tugasnya sehingga dapat meningkatkan kinerjanya. Di samping itu ketuntasan ini juga dipengaruhi oleh kerja sama dari guru dengan Kepala Sekolah dalam merencanakan program kerja sekolahnya masing masing.

c) Refleksi

Pada tahap ini akan dikaji apa yang telah terlaksana dengan baik maupun yang masih kurang baik dalam proses pembinaan melalui supervisi akademis Dari datadata yang telah diperoleh dapat duraikan sebagai berikut:

(1) Selama proses pembinaan Kepala Sekolah telah melaksanakan semua pembinaan dengan baik. Meskipun ada beberapa aspek yang belum sempurna, tetapi persentase pelaksanaannya untuk masing-masing aspek cukup besar.

(2) Berdasarkan data hasil pengamatan diketahui bahwa guru aktif selama proses pembinaan berlangsung.

(3) Kekurangan pada siklus-siklus sebelumnya sudah mengalami perbaikan dan 
peningkatan sehingga menjadi lebih baik.

(4) Hasil pembinaan kepala sekolah oleh Kepala Sekolah melalui supervisi akademis pada siklus III mencapai ketuntasan.

d) Revisi Pelaksanaan

Pada siklus III Kepala Sekolah telah melaksanakan pembinaan dengan baik dan dilihat dari peningkatan kinerja guru pelaksanaan pembinaan sudah berjalan dengan baik. Maka tidak diperlukan revisi terlalu banyak, tetapi yang perlu diperhatikan untuk tindakan selanjutnya adalah memaksimalkan dan mempertahankan apa yang telah ada dengan tujuan agar pada pelaksanaan pembinaan selanjutnya baik melalui supervisi akademik dapat meningkatkan kinerja guru sehingga tujuan pembinaan sebagai upaya meningkatkan mutu pendidikan dapat tercapai.

\section{Pembahasan}

1. Ketuntasan Hasil Pembinaan Kinerja Guru

Melalui hasil penelitian ini menunjukkan bahwa pembinaan melalui supervisi akademis Kepala Sekolah memiliki dampak positif dalam meningkatkan kinerja guru, hal ini dapat dilihat dari semakin mantapnya pemahaman guru terhadap pembinaan yang disampaikan Kepala Sekolah (Kinerja guru meningkat dari siklus I, II, dan III) yaitu masing-masing 41,18\% ; 70,59 \% ; 76,47 \% Pada siklus III kinerja guru secara kelompok dikatakan tuntas.

2. Kemampuan Kepala Sekolah dalam meningkatkan kinerja guru

Berdasarkan analisis data, diperoleh aktivitas guru dalam meningkatkan kinerjanya dalam setiap siklus mengalami peningkatan. Hal ini berdampak positif terhadap kinerja guru yaitu dapat ditunjukkan dengan meningkatnya nilai rata-rata kepala sekolah pada setiap siklus yang terus mengalami peningkatan.

3. Aktivitas Kepala Sekolah dan guru dalam Pembinaan melalui Supervisi Akademis

Berdasarkan analisis data, diperoleh aktivitas Kepala Sekolah dan guru yang paling dominan dalam kegiatan supervisi akademis adalah bekerja dengan menggunakan alat/media, mendengarkan/memperhatikan penjelasan Kepala Sekolah, dan diskusi antar antar guru dan Kepala Sekolah. Jadi dapat dikatakan bahwa aktivitas guru dapat dikategorikan aktif.

Sedangkan untuk aktivitas Kepala Sekolah selama pembinaan telah melaksanakan langkah-langkah metode pembinaan melalui supervisi akademis dengan baik. Hal ini terlihat dari aktivitas guru yang muncul di antaranya aktivitas membuat dan merencanakan program sekolah,melaksanakan, memberi umpan balik/evaluasi/tanya jawab di mana prosentase untuk aktivitas di atas cukup besar.

Berdasarkan hasil penelitian di atas, peningkatan kinerja guru melalui supervisi akademis Kepala Sekolah hasilnya sangat baik. Hal itu tampak pada pertemuan pertama dari 17 orang guru yang ada pada saat penelitian ini dilakukan nilai rata rata mencapai ; $41,18 \%$ meningkat menjadi 70,59\% dan pada siklus 3 meningkat menjadi 76,47 \%

Dari analisis data di atas bahwa pembinaan kinerja Kepala Sekolah melalui supervisi akademis Kepala Sekolah efektif diterapkan dalam upaya meningkatkan kinerja guru, yang berarti proses pembinaan Kepala Sekolah lebih berhasil dan dapat meningkatkan kinerja guru khususnya di SMK Negeri 2 Wonosari, oleh karena itu diharapkan kepada para Kepala Sekolah dapat melaksanakan pembinaan melalui supervisi akademis secara berkelanjutan 
Berdasarkan hasil penelitian di atas, peningkatan kinerja guru dalam pengembangan evaluas hasil belajar melalui supervisi akademik kepala sekolah kearah perubahan yang diinginkan mencapai $85 \%$ ketercapaiannya, maka kinerja guru tersebut dikatakan efektif. Dengan demikian maka hipotesis yang diajukan di atas dapat diterima.

\section{PENUTUP}

Berdasarkan analisis hasil penelitian dan diskusi dapat disimpulkan sebagai berikut:

1. Pembinaan Kepala Sekolah dalam upaya meningkatkan kinerja guru melalui supervisi akademis Kepala Sekolah menunjukan peningkatan pada tiap-tiap putaran (Siklus).

2. Aktivitas dalam kegiatan pembinaan menunjukan bahwa seluruh guru dapat meningkatkan kinerjanya dengan baik dalam setiap aspek.

3. Peningkatan kinerja guru oleh Kepala Sekolah melalui melalui supervisi akademis Kepala Sekolah ini menunjukan peningkatan pada tiap-tiap putarannya.

4. Aktivitas kepala sekolah menunjukan bahwa kegiatan pembinaan melalui melalui supervisi akademis Kepala Sekolah bermanfaat dan dapat membantu guru untuk lebih mudah memahami konsep peran dan fungsi guru sehingga kinerja guru dapat meningkat.

\section{DAFTAR PUSTAKA}

Arifin, I. 2000. Profesionalisme Guru: Analisis Wacana Reformsi Pendidikan dam Era Globalisasi. Simposium Nasional Pendidikan di Universitas Muhammadiyah Malang, 25-26 Juli 2001.

Arikunto, Suharsini. 2004. Dasar-dasar Supervisi. Jakarta: Rineka Cipta.

Atmodiwiro, Soebagio dan Soenarto Tatosiswanto, 1991. Kepemimpinan Kepala Sekolah, Semarang: Adhi Waskitho.

Bafadal Ibrahim, 1979. Supervisi Pengajaran Teori dan Aplikasinya dalam Membina Profesional Guru, Jakarta: Rineka Cipta.

Dedi Herawan, 2005. Pengembangan Model Supervisi Akademik Mata Pelajaran IPABiologi: Efektifitas Model Inovasi Supervisi Akademik Mata Pelajaran IPA Biologi dalam Upaya Meningkatkan Kinerja Guru IPA Biologi di SMU. Tesis Tidak diterbitkan UPI Bandung.

Semiawan, Conny. 1985. Bagaimana Cara Membina Guru Secara Profesional. Jakarta: Journal Pendidikan.

Sergiovani, Cs. 1975. "Beyond Human Relations" Profesional Supervision for Profesional Teachers. Washington DC: Association for supervision and Curiculum Development. 1979. Supercision: Human Prepectives. New York: MeGraw-Hill Book Company

Suyanto dan Djihad Hisya. 2000. Refleksi dan Reformasi Pendidikan Indoenesia Memasuki Millenium III. Adi Cita. Yogyakarta.

Tilaar, 1987. Futurisme dan Pengambilan Kebijakan pendidikan Menyongsong Abad-21. Pidato Pengukuhan Jabatan Guru Besar Tetap Perencanaan Pendidikan. IKIP Jakarta.

Yusuf A. Hasan. 2002. Pedoman Kepala Sekolahan Untuk Madrasah dan Sekolah Umum. Mekar Jaya. Jakarta. 
AKSARA: Jurnal Ilmu Pendidikan Nonformal

P-ISSN 2407-8018 E-ISSN 2721-7310 DOI prefix $\underline{10.37905}$

Volume 07, (03) September 2021

http://ejurnal.pps.ung.ac.id/index.php/Aksara 